\title{
Morphological Changes in the X-cells in Epidermal Papillomas of the Flatfish, Limanda schrenki
}

\author{
Fumio Yamazaki*, Toshihiko Hibino*, Keiichi Oishi*, and Takeo HaradA* \\ (Received February 9, 1978)
}

\begin{abstract}
1. Morphological changes in and the origin of the X-cells were studied in tumors diagnosed as epidermal papillomas of two specimens of Limanda schrenki reared for four months.

2. The X-cells originate from small cells $2-3 \mu \mathrm{m}$ in size, supposed to be wandering in nature, which first appear in the intercellular spaces of the basal layer of the epidermis.

3. The X-cells become recognisable at $4-5 \mu \mathrm{m}$ diameter and gradually swell, accumulating many vacuoles in the cytoplasm. They grow further to $15-20 \mu \mathrm{m}$ in size and then degenerate.
\end{abstract}

To date, epidermal papillomas of flatfish have been reported in at least 10 species along the Pacific coast of the United States ${ }^{1,2)}$ and Canada ${ }^{3,41}$ and seven species in the coastal waters of Japan. ${ }^{5-81}$ This tumor seems to be an epidemic or an endemic restricted mostly to the northern Pacific and has not yet been found in the Atlantic Ocean. ${ }^{91}$ The prevalences of this tumor differ between various flatish species and between different geographic areas. The highest prevalences recorded are $58.6 \%$ in young postmetamorphosed English sole from the west coast of Canada ${ }^{4 !}$ and $33 \%$ in adult Limanda shrenki in eastern Hokkaido, Japan." These tumors have characteristic X-cells, first named by Brooks et al. ${ }^{1 \prime}$ in papillomatous lesions. The X-cells found in the papillomas have identical features among the species ${ }^{81}$ and seem to occupy a key place in elucidating the mechanisms of papillomatous growth of flatfish skin. The origin and nature of the X-cell, however, are still not clear. The present study was carried out to clarify the morphological changes in and origin of the X-cells.

\section{Materials and Methods}

The specimens used in the present study were Limanda schrenki bearing epidermal papillomas. They were caught by standing net in Odaito Bay, facing the Nemuro Strait, eastern Hokkaido, on May 2, 1976 and were transported to the Faculty of Fisheries Hokkaido University, at Hakodate by a car equipped with containers. The fish were kept in an aquarium and fed with fresh or boiled mussels. The water temperature ranged from 9 to $15^{\circ} \mathrm{C}$. Two fish bearing tumors were killed October 9 . One of these had an epidermal papilloma on the eyed side and the other a papilloma extending from the posterior trunk of both sides up to the tips of the dorsal fin rays. The total lengths of the fish when fixed were $25 \mathrm{~cm}$ and $25.5 \mathrm{~cm}$ respectively. For assessing the area occupied by the tumor, transparent plastic sheets were first placed over each tumor followed by a sheet of paper in a way that allowed the basal area of the tumor to be easily traced on the paper without its getting wet. The traced areas on the paper were then weighed and the weights recorded were converted into percentage of the total area.

Both normal and papillomatous regions were fixed with Bouin's fluid and sectioned at $7 \mu \mathrm{m}$ after embedding in Tissue Prep (Fisher Scientific Co.). The sections were stained with Delafield's hematoxylin and eosin or Azan.

\section{Results}

The tumors occupied $11.1 \%$ and $22.1 \%$ of the total body surface of each fish at the beginning of rearing. These two fish were very healthy during the four-months rearing period and showed active feeding, giving $70 \%$ and $50 \%$ increases in body weight. This growth of the bodies of both fish was much greater than that of the tumors (38.2\% and $4.9 \%$ increase respectively). Normal parts of the epidermis of these fish is composed of stratified squamous or columnar epithelial cells (Fig. 1). The basal layer of the epidermis is germinative and composed of typical columnar cells attached to the basement membrane (Fig. 2).

* Faculty of Fisheries, Hokkaido University, Hakodate, Japan（山陭文雄・日比野利彦・大石圭一・原田武夫： 北海道大学水産学部) 
In papillomatous regions, undifferentiated small cells $2-3 \mu \mathrm{m}$ in size were observed very frequently in the basal layers of the epidermis in the transitional regions between normal and papillomatous part of the skin (Figs. 3, 4). These cells were also found in the dermis of the papillomatous regions and in the intercellular spaces and were irregular or amoebic in shape, sometimes flat or polygonal. The nuclei stained deeply and occupied the greater part of the cells. One conspicuous nucleolus of $1 \mu \mathrm{m}$ in size was observed in each nucleus, together with several scattered granular clumps of chromatin. These cells were easily identified among the normal stratified squamous epithelial cells because of their small size and deeply basophilic nature. They increased in number along the basement membrane, which resulted in detaching of the normal basal cells from the membrane. In places, the basal layer was occupied by these undifferentiated small cells (Fig. 5).

As the cells grew further to $4 \mu \mathrm{m}$ in size, the cytoplasm increased in volume and the nucleus became $2.5 \mu \mathrm{m}$ in size. At this stage, they could be identified as X-cells. They were still stained deeply and appeared frequently in the basal layer, but also scattered throughout the whole lesion.

The characteristic features of the X-cells appeared when they were $5 \mu \mathrm{m}$ in diameter. The cells at this size still occupied the basal layer, but sometimes they were observed in the middle layer of the epidermis. They were found singly or in groups among the normal epithelial cells and were sometimes surrounded by larger X-cells.

With further growth, the chromatin granules fused together to make a single giant nucleolus of 1-1.5 $\mu \mathrm{m}$ size (Fig. 6), the contours of the cells became smooth and round or elliptical in shape, and the cytoplasm became gradually vacuolated. The size of the cells continued to increase, parallel to that of the nuclei until they became $10 \mu \mathrm{m}$ in size; the nucleoplasm became homogeneous during this stage. After about $10 \mu \mathrm{m}$, the cytoplasm grew further as compared to the nucleus, and become more vesicular, giving a granular appearance. The prominent nucleoli were by now 1-2.5 $\mu \mathrm{m}$ in size. These X-cells were more numerous in the epidermis than in the dermis and occupied the basal part of the epidermis (Fig. 7). Some larger $\mathrm{X}$-cells were found to be attached to envelope cells. They grew further to $15 \mu \mathrm{m}$, their cytoplasm developed a fine vesicular network and they lost their stainability (Fig. 8). They further hypertrophied and progressed to degeneration in the final stages beyond the $15-20 \mu$ size. The prominent nucleoli also split into small granules at this stage.

\section{Discussion}

The present study suggests that the tumors of Limanda schrenki are clearly neoplastic, but not obviously malignant because, while the tumor grows progressively in size, feeding activity and the body growth seem to be almost normal. Histological observation revealed that the tumors have characteristic X-cells, which are swollen cells having vacuolated cytoplasm and weakly staining nuclei containing a giant nucleolus. The $\mathrm{X}$-cells have been described in tumors found in all five species of flatfish collected from the coastal waters of Hokkaido Island. ${ }^{81}$ The same cells have also been recorded in the tumors of other flatfish species sampled from the west coast of the United States and Canada. ${ }^{1,3)}$ In the final stage these cells are $15-20 \mu \mathrm{m}$ in size and 2-3 times the size of normal epithelial cells and have no counterpart in the normal epidermis. Therefore these cells are believed to be characteristic of the tumors diagnosed as epidermal papillomas. Morphological characteristics of these $\mathrm{X}$-cells are clarified in several tumor-bearing fiatfish species, ${ }^{1,3,81}$ but the origin of the X-cells are not made clear.

In our previous paper, ${ }^{8 !}$ the X-cells were suggested to originate from the undifferentiated small cells in Limanda schrenki and in Kareius bicoloratus. The present study provides data to support further this supposition. These small cells $2-3 \mu \mathrm{m}$ in size are thought to be wandering in nature and able to migrate between epidermis and dermis since they are found abundantly in the intercellular spaces and also found in both parts of the skin. They first appear in the basal part of the epidermis, the stratum germinativum, from where normal epithelial cells originate. This fact suggests that the small cells are derived from epithelial cells, though they are, however, quite different from normal covering epithelial cells in that they have no polarity and joining apparatus.

It is interesting to note that the smallest lesions identified as angioepithelial nodules are usually composed of small cells and vascular connective tissue of dermal origin with no differentiated X-cells overlain by epidermis of normal appearance. MCARN et al. ${ }^{101}$ established the histopathologic identity of the skin tumors of flatfish and classified them into three morphological types, the angio- 
epithelial nodule, the angioepithelial polyp and the epidermal papilloma. Study of the morphological and cytological transitions from the angioepithelial nodule to epidermal papilloma is essential to elucidate the origin of the wandering small cells.

An important problem that must be solved is whether the X-cells proliferate themselves to replace the normal epithelial cells, or normal epithelial cells transform into X-cells. It is reasonable to say from the results of the present observations that the X-cells replace the normal epithelial cells, because the small cells occupying the basal part of the epidermis proliferate and scatter around to give rise to the $\mathrm{X}$-cells. The $\mathrm{X}$-cells show conspicuous morphological changes from $2 \mu \mathrm{m}$ to $20 \mu \mathrm{m}$ and finally degenerate; these changes are never found in normal epithelial cells. Furthermore, these X-cells at a later stage become surrounded by envelope cells which might play some role in the degeneration of the cells.

Epidermal papillomas have been found also in gobies. ${ }^{11,121}$ The histological features are almost the same as those of the flatfish and X-cells have also been found in the lesions*. Kimura et al. ${ }^{12}$ have described the giant cells in the papillomatous lesions of the goby, Acanthogobius favimanus and also pointed out the small cells in the lesions. To make clear the intrinsic nature of the papillomas of flatfish and gobies, it is important to know the mechanism of proliferation and the different stages that the small cells follow.

\section{Acknowledgements}

We wish to thank the Science and Technology Agency, the Prime Minister's Office, Japanese
Government for a grant to carry out the present study and Professor Hamada, and Dr. Onozato of the Faculty of Fisheries, Hokkaido University for their help in the course of the present study. Thanks are also offered to Dr. A. B. Acton, Department of Zoology, Dr. H. F. Stich, Cancer Research Center, University of British Columbia and Mr. S. Y. Mishrigi for their reading and correcting the manuscript.

\section{References}

1) R.E. Brooks, G.E. MCARN, and S.R. Wellings: J. Nat. Cancer Inst., 43, 97-109 (1969).

2) S.R. Wellings, B.B. McCain, and B.S. Miller: Prog. exp. Tumor Res., 20, 55-74 (1976).

3) H.F. Stich and A.B. Acton: Prog. exp. Tumor Res., 20, 44-54 (1976).

4) H.F. Stich, A.B. Acton, and C.R. Forrester: J. Fish. Res, Board, Can., 33, 1993-2001 (1976).

5) I. Kimura, T. Sugiyama, and Y. Ito: Proc. Soc. Exp. Biol. Med., 125, 175-177 (1967).

6) Y. Honma and T. Kon: Bull. Japan. Soc. Sci. Fish., 34, 1-5 (1968).

7) K. OISH, F. YAMAZAKI, and T. HARADA: J. Fish. Res. Board Can., 33, 2011-2017 (1976).

8) F. Yamazaki, T. Hibino, K. Oishi, T. Harada, H. F. STICH, and A. B. Acton: Bull. Japan. Soc. Sci. Fish., 44, 407-413 (1978).

9) H. F. Stich, A. B. Acton, K. Oishi, F. Yama ZAKI, T. HARADA, T. Hibino, and H. G. Moser: Annals New York Acad. Sci., 298, 374-388 (1977).

10) G. E. MCArn, R. G. Chuinard, B. S. Miller, R. E. Brooks, and S. R. Wellings: J. Nat. Cancer Inst., 41, 229-242 (1968).

11) K. OотA: Gann., 43, 264-265 (1952).

12) I. Kimura, T. MiYake, and Y. Ito: Fish Patho$\log y$, 5, 85-99 (1971).

\footnotetext{
* Yamazaki, Hibino, and NaKamura (1977) described the X-cells in tumor-bearing gobies, Acanthogobius flavimanus, in Hakodate Bay.
} 


\section{Explanation of Plate}

Fig. 1. Normal epidermis of Limanda schrenki having tumors on both sides of the body. $\times 700$

Fig. 2. High magnification of basal part of the normal epidermis (stratum germinativum), Note regularly arranged columnar basal cells. $\times 1740$

Fig. 3. High magnification of basal part of the epidermis of transitional region between the normal and papillomatous lesions. Note small wandering cells in the intercellular spaces of the basal cells. $\times 1740$

Fig. 4. Transitional region of the normal and papillomatous lesions. Many small cells are found in the basal cell layer. $\times 700$

Fig. 5. High magnification of the basal layer which is occupied by the small cells. They are irregular in shape and stain deeply with $\mathrm{H} \& \mathrm{E}$. Note the basal cells lifted up and separated from the basement membrane. $\times 1740$

Fig. 6. Photograph showing cells transitional from the small cells to the $X$-cells in the lower part of the epidermis. $\times 1600$

Fig. 7. Photograph showing lower part of the epidermis occupied by the differentiated X-cells. $\times 1740$

Fig. 8. X-cells which are greatly swollen just before degeneration. $\times 1740$ 

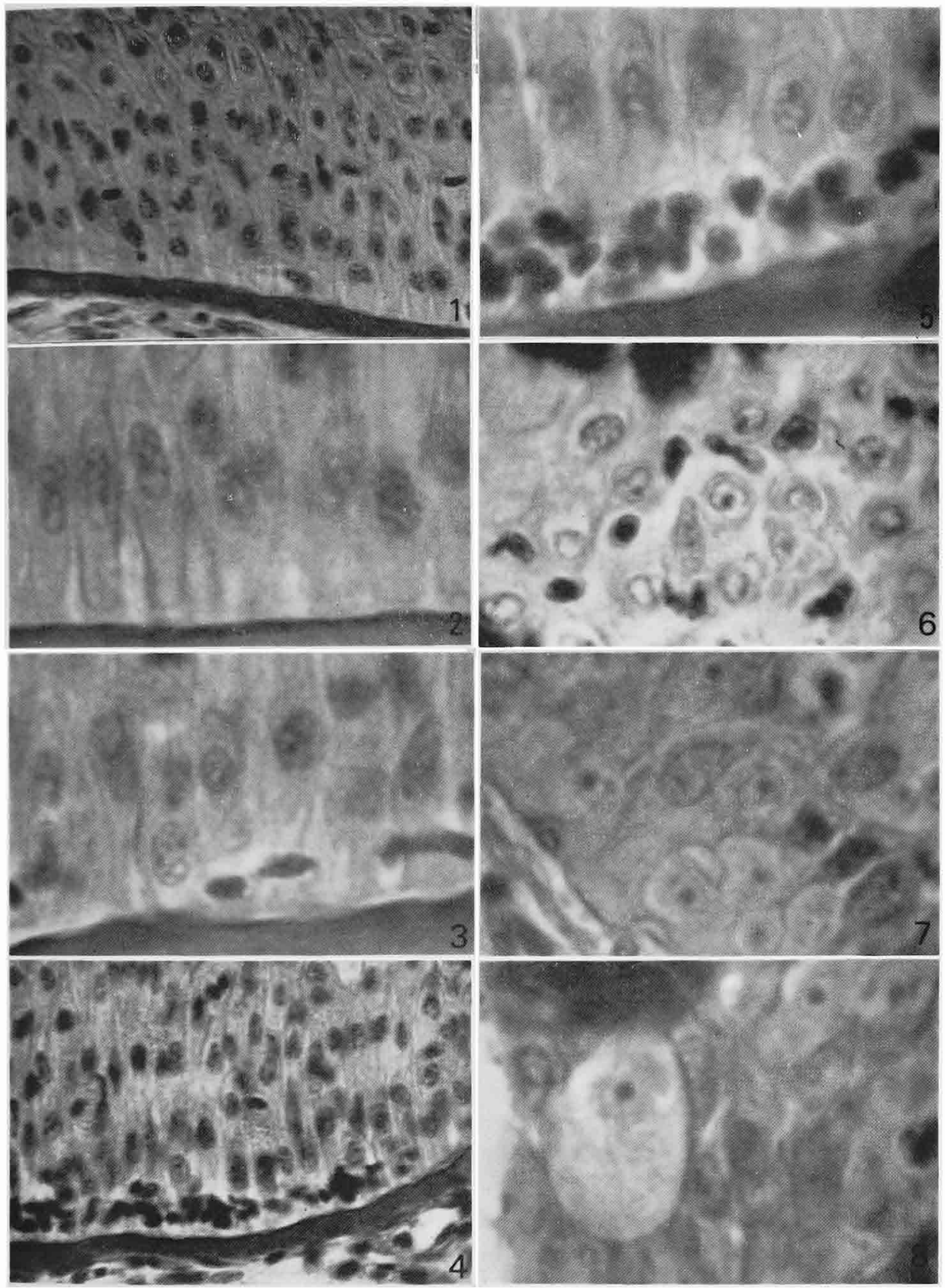